\title{
Lutz Creek watershed, Barro Colorado Island, Republic of Panama
}

\author{
Matthew Larsen ${ }^{1}$, Robert Stallard ${ }^{2}$, and Steven Paton ${ }^{1}$ \\ ${ }^{1}$ Smithsonian Tropical Research Institute \\ ${ }^{2}$ U.S. Geological Survey
}

September 24, 2020

\section{Watershed description:}

The watershed is underlain by Oligocene tuffaceous and fossiliferous sandstone bedrock, rich in calcite, and clay-rich (Smectite) soils overlie a thick saprolite (Baille et al., 2007). BCI ranges in elevation from $26 \mathrm{~m}$ asl to $167 \mathrm{~m}$ asl, is fully forested, with what has been characterized as a lowland seasonal tropical forest, with a mix of deciduous and evergreen trees. Annual rainfall averages 2,580 mm, with strong seasonality: the dry season is from December to May. BCI is one of the most intensively studied area of the global tropics because of the century-long presence of a research station and ongoing scientific investigation focused mainly on terrestrial forest ecology, entomology, animal behavior and related fields. The Lutz Creek data improve our understanding of basic hydrological processes and inform our ongoing research into the complex terrestrial ecosystems of the island and the region [bibliography below]. BCI is also home to the first of what is now a global network of more than 70 forest research plots known as the Forest Global Earth Observatory (ForestGEO, see https://forestgeo.si.edu/ ). ForestGEO is dedicated to advancing long-term study of the world's forests to strengthen science capacity in an era of rapidly changing landscapes and climate to understand and predict forest dynamics

\section{Bibliography:}

Albrecht, L., Stallard, R.F., and Kalko, E., K. V. 2017. Land use history and population dynamics of free-standing figs in a maturing forest. PLoS ONE $\mathbf{1 2}$ (5): e0177060 [http://journals.plos.org/plosone/article?id=10.1371/journal.pone.0177060]

Anderson-Teixeira, K.J., Davies, S.J., Bennett, A.C., et al. 2015. CTFS-ForestGEO: a worldwide network monitoring forests in an era of global change. Global Change Biology 21 (2): 528-549 DOI :10.1111/gcb.12712

Baillie, I., Elsenbeer, H., Barthold, F., Grimm, R., and Stallard, R.F. 2007. Semi-detailed soil survey of Barro Colorado Island, Panama: Balboa, Republic of Panama, Smithsonian Tropical Research Institute, p. 54. [http://biogeodb.stri.si.edu/bioinformatics/bci_soil_map/documentation/BCI_soil_report_complete.pdf]

Barthold, F.K., Tyralla, C., Schneider, K., Vaché, K.B., Frede, H.-G., and Breuer, L. 2011. How many tracers do we need for end member mixing analysis (EMMA)? A sensitivity analysis. Water Resources Research47 W08519: 1-14

Dietrich, W.E., Windsor, D.M., and Dunne, T. 1982. Geology, climate, and hydrology of Barro Colorado Island, in Leigh, E.G.J., Rand, A.S., and Windsor, D.M. eds., The Ecology of a Tropical Forest Seasonal Rhythms and Long-term Changes : Washington D.C. Smithsonian Institution Press. p. 21-46

Godsey, S.E., Elsenbeer, H., and Stallard, R.F. 2004. Overland flow generation in two lithologically distinct rainforest catchments. Journal of Hydrology 295 (1-4): 276-290 [http://www.sciencedirect.com/science/article/pii/S0022169404001799] 
Johnsson, M.J., and Stallard, R.F. 1989. Physiographic controls on the composition of sediments derived from volcanic and sedimentary terrains on Barro Colorado Island, Panama. Journal of Sedimentary Petrology 59 (5): 768-781. [http://jsedres.sepmonline.org/content/59/5/768.abstract]

Kinner, D.A., and Stallard, R.F. 2004. Identifying storm flow pathways in a rainforest catchment using hydrological and geochemical modelling.Hydrological Processes 18 (15): 2851-2875 [http://water.usgs.gov/nrp/proj.bib/Publications/kinner.stallard.pdf]

Leigh, E.G.J., Rand, A.S., and Windsor, D.M. eds. 1982. The Ecology of a Tropical Forest: Seasonal Rythms and Long Term Changes.Smithsonian Institution Press. Washington, D.C. 468 p

Windsor, D.M. 1990. Climate and Moisture Variability in a Tropical Forest: Long-term Records from Barro Colorado Island, Panamá:Smithsonian Institution Press, Smithsonian Contributions to the Earth Sciences . Washington, D.C., U.S.A. 29.145 p

Zimmermann, B., and Elsenbeer, H. 2008. Spatial and temporal variability of soil saturated hydraulic conductivity in gradients of disturbance. Journal of Hydrology 361 : 78-95

Zimmermann, B., Elsenbeer, H., and De Moraes, J.M. 2006. The influence of land-use changes on soil hydraulic properties: Implications for runoff generation. Forest Ecology and Management 222 : 29-38

Zimmermann, B., Zimmermann, A., Lark, R.M., and Elsenbeer, H. 2010. Sampling procedures for throughfall monitoring: A simulation study. Water Resources Research 46 (W01503): 1-15

\section{Hosted file}

Larsen.pdf available at https://authorea.com/users/361185/articles/482694-lutz-creekwatershed-barro-colorado-island-republic-of-panama 